\title{
Physicochemical Characteristics of Surface Water and Sediment of Silver River, Southern ljaw, Bayelsa State, Niger Delta, Nigeria
}

\author{
Edori Onisogen Simeon", Kieri Ben Smith Idomo, Festus Chioma \\ Department of Chemistry, Faculty of Natural and Applied Sciences, Ignatius Ajuru University of Education, Rumuolumeni, Nigeria \\ Email address: \\ onisogen.edori@yahoo.com (E. O. Simeon) \\ ${ }^{*}$ Corresponding author \\ To cite this article: \\ Edori Onisogen Simeon, Kieri Ben Smith Idomo, Festus Chioma. Physicochemical Characteristics of Surface Water and Sediment of Silver \\ River, Southern Ijaw, Bayelsa State, Niger Delta, Nigeria. American Journal of Environmental Science and Engineering. \\ Vol. 3, No. 2, 2019, pp. 39-46. doi: 10.11648/j.ajese.20190302.12
}

Received: September 11, 2019; Accepted: October 7, 2019; Published: October 21, 2019

\begin{abstract}
Water and sediment samples were collected from Silver River to determine the levels of various physicochemical parameters in both sediment and water from the river. This research was conducted with the aim of determining the extent of deterioration of the river as a result of artisanal refining of crude oil. The result obtained showed that the mean values of the different parameters examined in the water were; conductivity $(26,567 \pm 464.28 \mu \mathrm{S} / \mathrm{cm})$, total dissolved solids (TDS), $(13,250 \pm 187.08 \mathrm{mg} / \mathrm{L})$, total suspended solids (TSS), $(17.78 \pm 3.07 \mathrm{mg} / \mathrm{L})$, turbidity $(15.57 \pm 2.45 \mathrm{NTU}), \mathrm{pH}(7.12 \pm 0.03)$, salinity $(8766.67 \pm 449.69 \mathrm{mg} / \mathrm{L})$, total hydrocarbon content $(\mathrm{THC})(45.43 \pm 3.86 \mathrm{mg} / \mathrm{L})$, nitrates $\left(\mathrm{NO}_{3}{ }^{-}\right),(4.93 \pm 0.61 \mathrm{mg} / \mathrm{L})$, sulphates $\left(\mathrm{SO}_{4}{ }^{2-}\right)(1471.07 \pm 1058.43 \mathrm{mg} / \mathrm{L})$, phosphates $\left(\mathrm{PO}_{4}{ }^{3}\right),(0.64 \pm 0.16 \mathrm{mg} / \mathrm{L})$, dissolved oxygen (DO), $(4.73 \pm 0.57 \mathrm{mg} / \mathrm{L})$, biochemical oxygen demand (BOD), $(33.20 \pm 2.33 \mathrm{mg} / \mathrm{L})$ and chemical oxygen demand (COD), $(50.13 \pm 3.21 \mathrm{mg} / \mathrm{L})$. Physicochemical parameters such as conductivity, TDS, salinity, THC, $\mathrm{SO}_{4}{ }^{2-}, \mathrm{DO}, \mathrm{BOD}$ and COD fall below the standard requirement for domestic water consumption, while TSS, turbidity, $\mathrm{pH}, \mathrm{NO}_{3}{ }^{-}$and $\mathrm{PO}_{4}{ }^{3-}$ were within the acceptable range for drinking water by WHO. The mean values of sediment physicochemical parameters were; $\mathrm{pH}(7.20 \pm 0.03)$, conductivity $(16701.67 \pm 513.65 \mu \mathrm{S} / \mathrm{cm})$, total organic carbon (TOC) $(2.37 \pm 0.05 \%)$ and total organic matter (TOM) $(4.09 \pm 0.09 \%)$. The particle size examination showed that clay was $7.33 \pm 1.25 \%$, silt $(14.67 \pm 1.25 \%)$ and sand $(78.00 \pm 1.63 \%)$. The examined sediment nutrient species showed that the mean values were $0.51 \pm 0.01,8.81 \pm 12.09$ and $0.27 \pm 0.01 \mathrm{mg} / \mathrm{kg}$ for $\mathrm{NO}_{3}{ }^{-}, \mathrm{SO}_{4}{ }^{2-}$ and $\mathrm{PO}_{4}{ }^{3-}$ respectively. The findings of this work showed that the silver river (both water and sediment) are under human influence which not handled in the immediate, can in the near future constitute a major health risk to the entire environment.
\end{abstract}

Keywords: Water, Sediment, Physicochemical Characteristics, Silver River, Pollution

\section{Introduction}

The river system is the major source of fresh water. It carries along its course and tributaries a reasonable quantity or load of matter which are either in dissolved or particulate form. These may have originated from both natural and anthropogenic sources [1]. Rivers are known to play major roles in transportation of goods and services. Also, they are involved in the transportation of wastes arising from both municipal, domestic and industrial wastes. Runoffs from agricultural farms and other pollutant generating sources eventually are deposited in water columns of rivers which therefore, introduce pollutants into the river [2].

Due to the incessant increase in population growth, which is accompanied with rapid urbanization and industrial activities, discharges of wastes into the aquatic environment is on the increase. Aquatic flora and fauna are always in continuous contact with water, which implies that they are directly affected by any change in water quality. Over exploitation and exploration of the natural environment without recourse to laid down rules or principles results in the deposition of toxic substances in the ecosystem [3]. Contaminants which originated from agricultural waste, factory discharge channels and 
effluents sources are discharged into the environment, which enhances or increases the total contaminant burden of the receiving environment (whether aquatic or terrestrial). Furthermore, the degree and nature of the movement of contaminants is dependent on the characteristics of the source and the receiving environment [4].

Physiochemical properties of sediment and water such as $\mathrm{pH}$, conductivity, total organic carbon, total organic matter, etc. determines the level or the extent to which heavy metals can be retained in the media. These help in the adsorption, absorption, desorption, solubility, movement and toxicological properties of the metals [5]. Therefore, the study of heavy metals in any media or space can better be done in association with the physicochemical qualities of that environment.

\section{Materials and Methods}

\subsection{Collection of Water and Sediment Samples}

Water samples were collected with pre-rinsed plastic bottles below the water surface at a depth of about $20 \mathrm{~cm}$ and corked immediately, while sediment samples were collected with plastic trowel and put into cellophane bags. The samples were immediately transferred into ice-chest containers without further treatment and then transported to the laboratory.

\subsection{Preparation of Sediment Samples}

Sediment samples were air dried in the laboratory to constant weight. The dried samples were powdered with mortar and pestle and sieved with $2 \mathrm{~mm}$ mesh. Pebbles and solid material were removed uncrushed. The samples were then ready for further processing for physicochemical analysis.

\subsection{Analysis of Water Samples for Physicochemical Parameters}

The water samples were analyzed for physicochemical parameters as follows: Turbidity, total dissolved solids (TDS), electrical conductivity, water hardness, salinity, hydrogen potential $(\mathrm{pH})$ and dissolve oxygen (DO) were done in-situ using U-52 multi parameter water checker Horriba.

Total suspended solids (TSS) was done by filtration method, where a previously weighed filter paper was reweighed and the weight difference taken as the TSS value. Nitrate concentrations were achieved by the use of nitrover tablets dissolved in $100 \mathrm{ml}$ of water and the concentrations read off from Wagtech Spectrophotometer model 5000 and compared standard charts provided. The concentrations of sulphates were determined spectrophotometrically after $5 \mathrm{ml}$ of a conditioning reagent was added to $100 \mathrm{ml}$ of water and a spatula full quantity of $\mathrm{BaCl}$ mixture. The result obtained were compared with a calibrated result.
The biochemical oxygen demand (BOD) was determined with the same instrument used for DO after the sample has been incubated for five days in a dark cupboard (BOD cupboard). Titrimetric method was used to determine the value of chemical oxygen demand (COD). The colorimetric end point technique was used to determine the concentrations of phosphates in the water samples. Then the concentration of phosphate was determined spectrophotometrically at $490 \mathrm{~nm}$ wavelength. The result was compared with those in a prepared chart of calibration curve of standard phosphate solution. Total hydrocarbon content of the water was determined with a $\mathrm{HACH}$ spectrophotometer after being extracted with toluene.

\subsection{Physicochemical Analysis of Sediment Samples}

\subsection{1. pH and Electrical Conductivity Determinations}

The $\mathrm{pH}$ of the sediment samples was determined by mixing 1:1 $(/ \mathrm{w})$ of deionized water and sediment samples and the $\mathrm{pH}$ determined with the Horiba water checker. Electrical conductivity was also determined by the same volume/weight method and subsequent measurement with the water checker instrument earlier mentioned.

\subsubsection{Determination of Nutrient Parameters}

The nutrient parameters $\left(\mathrm{NO}_{3}^{-}, \mathrm{SO}^{4-}, \mathrm{PO}_{4}{ }^{3-}\right)$ were determined after distilled water and sediment mixture has been homogenized, then the application of the different procedures applied for each of them in the water analysis was used and the result recorded.

\subsubsection{Determination of Total Organic Carbon and Total Organic Matter}

Total organic carbon (TOC) was examined using the method of Walkey and Black [6], with slight modifications as was carried out by Marcus and Edori, [7]. Total organic matter was obtained by multiplying $\% \mathrm{TOC} \times 1.729$.

\subsubsection{Determination of the Textural Class and Percentage Composition of Soil Components}

The sediment texture determination was done using the hydrometer method where sodium hexametaphosphate is the dispersant. The sediment sample was placed in the hydrometer and the dispersant added. The contents were shaken together and allowed to settle under gravity. The sediment samples then settle down at the bottom of the hydrometer based on their sizes. The larger particles settled first before the fine ones. The percentage of each of the sediment components or type was then calculated based on the value observed or read off from the hydrometer. Then the textural class determined based on the percentages of the different classes.

\section{Results}

The result of the physical, chemical, nutrients and gross organic characteristics of the water and sediment samples from Silver River are given in Tables 1-4. 
Table 1. Physical Parameters of Water Samples from Different Stations in Silver River.

\begin{tabular}{|c|c|c|c|c|c|}
\hline \multirow{2}{*}{ Parameters } & \multicolumn{3}{|c|}{ Stations } & \multirow{2}{*}{ Mean \pm SD } & \multirow[b]{2}{*}{ WHO Standard } \\
\hline & 1 & 2 & 3 & & \\
\hline Conductivity $(\mu \mathrm{S} / \mathrm{cm})$ & 26,100 & 27,200 & 26,400 & $26,567 \pm 464.28$ & $1000-5000$ \\
\hline TDS (mg/L) & 13,050 & 13,500 & 13,200 & $13,250 \pm 187.08$ & 2000 \\
\hline $\mathrm{TSS}(\mathrm{mg} / \mathrm{L})$ & 14.23 & 21.71 & 17.40 & $17.78 \pm 3.07$ & 50 \\
\hline Turbidity (NTU) & 12.5 & 18.5 & 15.7 & $15.57 \pm 2.45$ & 15 \\
\hline
\end{tabular}

Table 2. Chemical and Nutrient Parameters of Water Samples from Different Stations in Silver River.

\begin{tabular}{llllll}
\hline \multirow{2}{*}{ Parameters } & Stations & & Mean \pm SD & WHO Standard \\
\cline { 2 - 4 } & $\mathbf{1}$ & $\mathbf{2}$ & $\mathbf{3}$ & $7.12 \pm 0.03$ & $6.5-8.5$ \\
$\mathrm{pH}$ & 7.12 & 7.06 & 7.14 & $8766.67 \pm 449.69$ & 2000 \\
$\mathrm{Salinity}(\mathrm{mg} / \mathrm{L})$ & 8,200 & 9,300 & 49.800 & $45.43 \pm 3.86$ & 20 \\
$\mathrm{THC}(\mathrm{mg} / \mathrm{L})$ & 40.3 & 5.6 & 4.4 & $4.93 \pm 0.61$ & 20 \\
$\mathrm{NO}_{3}{ }^{-}(\mathrm{mg} / \mathrm{L})$ & 4.2 & 2,455 & 2.9 & $1471.07 \pm 1058.43$ & 500 \\
$\mathrm{SO}_{4}{ }^{-2}(\mathrm{mg} / \mathrm{L})$ & 1,956 & 0.85 & 0.63 & $0.64 \pm 0.16$ & 5.0 \\
$\mathrm{PO}_{4}{ }^{--}(\mathrm{mg} / \mathrm{L})$ & 0.45 & & &
\end{tabular}

Table 3. Gross Organic Parameters of Water Samples from Different Stations in Silver River.

\begin{tabular}{|c|c|c|c|c|c|}
\hline \multirow{2}{*}{ Parameters } & \multicolumn{3}{|c|}{ Stations } & \multirow{2}{*}{ Mean \pm SD } & \multirow{2}{*}{ WHO Standard } \\
\hline & 1 & 2 & 3 & & \\
\hline $\mathrm{DO}(\mathrm{mg} / \mathrm{L})$ & 5.4 & 4.0 & 4.8 & $4.73 \pm 0.57$ & 10 \\
\hline BOD mg/L) & 30.7 & 36.3 & 32.6 & $33.20 \pm 2.33$ & 4 \\
\hline $\mathrm{COD}(\mathrm{mg} / \mathrm{L})$ & 46.5 & 54.3 & 49.6 & $50.13 \pm 3.21$ & 10.4 \\
\hline
\end{tabular}

Table 4. Physicochemical Parameters of Sediment Samples from Different Stations in Silver River.

\begin{tabular}{lllll}
\hline \multirow{2}{*}{ Physicochemical Parameters } & Stations & & & \multirow{2}{*}{ Mean \pm SD } \\
\cline { 2 - 5 } & $\mathbf{1}$ & $\mathbf{2}$ & $\mathbf{3}$ & $7.20 \pm 0.03$ \\
$\mathrm{pH}$ & 7.25 & 7.18 & 16,100 & $16701.67 \pm 513.65$ \\
Conductivity $(\mu \mathrm{S} / \mathrm{cm})$ & 16,650 & 17,355 & 2.35 & $2.37 \pm 0.05$ \\
\%TOC & 2.32 & 2.44 & 4.05 & $4.09 \pm 0.09$ \\
\%TOM & 4.00 & 4.21 & 6 & $7.33 \pm 1.25$ \\
\% Clay & 9 & 7 & 16 & $14.67 \pm 1.25$ \\
\% Silt & 15 & 13 & 78 & $78.00 \pm 1.63$ \\
\% Sand & 76 & 80 & Loamy sand & - \\
Textural Class & Loamy sand & 0.52 & 0.521 & $0.51 \pm 0.01$ \\
$\mathrm{NO}_{3}^{-}(\mathrm{mg} / \mathrm{Kg})$ & 0.50 & 0.27 & 25.9 & $8.81 \pm 12.09$ \\
$\mathrm{SO}_{4}{ }^{3-}(\mathrm{mg} / \mathrm{Kg})$ & 0.25 & 0.27 & 0.26 & $0.27 \pm 0.01$ \\
$\mathrm{PO}_{4}{ }^{3-}(\mathrm{mg} / \mathrm{Kg})$ & 0.28 & & & \\
\hline
\end{tabular}

\section{Discussion}

\section{1. pH, Physical Parameters and Salinity of Water and Sediment Samples}

Physicochemical parameters reveal underlying properties of water and give insight into the portability of water for both human and industrial uses.

\subsection{1. $\mathrm{pH}$}

The values of the $\mathrm{pH}$ obtained in water and sediment samples from the Silver River varied from $7.06-7.04$ and $7.12-7.25$. These values indicated slightly basic or alkaline $\mathrm{pH}$. The values fall within the recommended value for drinking water. $\mathrm{pH}$ values give information on the amount of heavy metals that are likely present in either water or sediment media [8]. The $\mathrm{pH}$ values obtained in water samples from the present work is similar to the work of Ekpete [9], but higher than those obtained by Iyama et al., [10] in Sagbama Creeks and those observed in New Calabar River at designated discharged points [11]. Similarly, the values of $\mathrm{pH}$ obtained in the sediment is higher than those observed in sediments along effluents discharge points in the New Calabar River [12]. In water or sediments, acidic or alkaline values indicated the capacity of the media to hold heavy metals and dissolve more electrolytic ions in solution [13] and also affects the holding ability of nutrient components and levels in the sediment or water and thus determine their quality [14]. Naturally, water $\mathrm{pH}$ usually occurs within range of 4 to 9 and any sediment or water that has values in the region of alkalinity is likely to have the presence of bicarbonate and carbonates of alkali and alkaline earth metals [15].

\subsubsection{Conductivity}

The conductivity values for both water and sediment samples from the river varied from 26,100 - 27,200 and $16,100-17,355 \mu \mathrm{S} / \mathrm{cm}$ respectively. The observed values of Conductivity in the water phase of the river is very high when compared with the WHO standard of 1000 - 5000 $\mu \mathrm{S} / \mathrm{cm}$ value. Conductivity describes the capacity of a material (whether liquid or solid), to allow the passage of 
electricity through it. It is influenced by the existence or absence of dissolved solids such as the salts of $\mathrm{Ca}, \mathrm{Mg}, \mathrm{Na}$, $\mathrm{K}$ and $\mathrm{Cl}$ and charge carrying ions in either water or sediment samples [16]. The conductance of any material or medium is a function of the number of ions present and is used to predict the concentration of ions or mineral present in the medium [17-19], but cannot be used to determine the specific ion present. The observed high value of conductivity in the present work may be related to influence of sea water on the river during high tide. The values obtained in this work are higher than those of other authors in a similar environment $[11,18]$.

\subsubsection{Total Dissolved Solids (TDS)}

The total dissolved solids in water samples varied from $13,050-13,500 \mathrm{mg} / \mathrm{L}$. This value is very high when compared with the WHO recommended value of $2000 \mathrm{mg} / \mathrm{L}$ for domestic water use. The increased value may be a consequence of salt water incursion, human input through bunkering activities and the redox potential of the water system [5]. The values in the present work are higher than the values observed in the upper reaches of Orashi River [20] and a stretch of the New Calabar River [21]. TDS in water measures the presence of both inorganic an organic material which are in solution [19]. The level to which pollution has affected water or aquatic environment can be related to the quantity or level or concentration of TDS present. TDS is a good indicator of water quality due to the fact that it affects the taste, colour and smell of the water and also increase the ability of to allow light penetration. Increased levels of TDS make water not fit for drinking and irrigation of farmlands, cause decreased photosynthetic capacity and rise in water temperature [22].

\subsubsection{Total Suspended Solids (TSS)}

The value of TSS observed in the present work fall within the range of $14.23-17.40 \mathrm{mg} / \mathrm{L}$ in the water samples. The observed values are lower than the desired value for drinking water recommended by WHO. Increased TSS in water increases the turbidity of the water. Factors which affects the TSS of water include; the farming system, building and constructions works, mining and season (wet or dry). All these factors leads to the exposure of the soil surface and thus giving room for runoffs and erosion, which transported particles to the water. Suspended particles are more of natural occurrence than artificially induced are majorly composed of components like algae, silt and sediment. Sediment resuspension resulting from the nature of water flow and current type also affects the TSS. Though, superfluous concentrations more than the background value is a result of human interference [11]. Increased suspended particles level in water give information on the extent of contamination of the water and also responsible for some organoleptic properties of water namely; odour and colour [23].

\subsubsection{Salinity}

The salinity values obtained in the present research varied from $8,200-9,300 \mathrm{~g} / \mathrm{L}$. This value is higher than the WHO requirement of $2000 \mathrm{mg} / \mathrm{L}$ for drinking water. Salinity, expresses the amount of salt content of water or soil environment. The observed values are higher than those of Iyama and Edori [5], in Bassan Rivers and Iyama et al. [10], in Sagbama Rivers. The very high value of salinity is an indication of salt water influences from the sea.

\subsubsection{Turbidity}

The values of turbidity observed in the present work ranged from 12.5 - 18.5 NTU. This value is higher than the WHO value of 10 NTU for portable water. Turbidity is the degree of clearness or opaqueness of water. The values of turbidity observed in this work is higher than those of Edori and Nna [11], in the New Calabar and those of Yapo et al. [24], in a river in Abidjan City. The level of suspended and dissolved particles in any water environment give high turbidity to the environment. The high turbidity value may have originated from bunkering activities which discharge effluents without following due procedures and also from incessant dredging activities rampant in the area. Another possible reason might be from the amount of dissolved solids (organic or inorganic Materials) present in the river as observed in the present work. Effects of high turbidity include prevention of light penetration, hindrance to photosynthetic activities and destruction of the normal aquatic life and also reduce the value and appearance of surface water [25]. The concentrations or the amount of micro-organisms, phytoplanktons and zooplanktons increases water turbidity $[11,23]$.

\subsection{Gross Organic Matter of Water Samples}

\subsubsection{Dissolved Oxygen (DO)}

Dissolved oxygen content of the examined water samples from Silver River varied from 4.0 to $5.4 \mathrm{mg} / \mathrm{L}$, which is lower than the required value of $10 \mathrm{mg} / \mathrm{L}$ required by WHO. DO is an important parameter in water analysis based on the fact that life in aquatic environment is a function of its availability. The observed values of DO in the present work corroborates the findings of Edori and Nna [11], in a polluted water environment, but at variance with the study of Iyama et al. [10], in Sagbama Creeks. The cause of the low level of DO as observed might be the oil waste clearly visible on the surface of the water, a product of bunkery and sometimes oil spill. It is used to derive information on the level and extent of bacterial activity, photosynthetic characteristics, the abundance of nutrients and the ability of fishes to survive in that environment [26]. Temperature is a major factor that determines the amount of dissolved oxygen present in water. High temperature reduces DO and promotes increased microbial growth [27].

\subsubsection{Biochemical Oxygen Demand (BOD)}

The range of values obtained for BOD in the water samples from the river ranged from $30.7-36.5 \mathrm{mg} / \mathrm{L}$. These values are higher than the WHO value of $4.0 \mathrm{mg} / \mathrm{L}$. This revealed a water seriously contaminated and so, not suitably for consumption. The values obtained in other work [11, 28], 
were lower than the ones observed in the present work. BOD is a measure of organic contaminants and the microbial action on such materials, in places where defecation is directly done on the river (the behaviour of shore dwellers), it is expected to be high. used to express the level contamination of water by organic material. High values depicts continuous breakup of biological and more or less mineral by microbes [29].

\subsubsection{Chemical Oxygen Demand (COD)}

The concentrations range for $\mathrm{COD}$ in observed ranged from $46.5-54.3 \mathrm{mg} / \mathrm{L}$. This is above the WHO requirement of $10 \mathrm{mg} / \mathrm{L}$ for consumption. COD give information on the level or content of oxidizable organic component that might be responsible for river or water pollution. The redox potential of any river environment requires a given quantity or amount of oxygen that can effectively oxidize organic matter present. The amount of Oxygen that participated in the oxidation process is what is referred to as COD [30]. COD is a notable parameter of environmental health importance that is used as one of the tools to determine the portability of water for drinking.

\subsubsection{Total Hydrocarbon Content (THC)}

The total hydrocarbon content of the present work varied between $40.3-49.4 \mathrm{mg} / \mathrm{L}$. This value is greater than the recommended value of $20 \mathrm{mg} / \mathrm{L}$ by WHO. The source of the THC in the river as observed is from illegal bunkering activities present within the river coast. The values obtained in this work were either higher or within the range observed by Howard et al [31], in oil polluted wetland of Niger Delta, but were higher than those observed by Wokoma [32] in Sombreiro River. Increased value or concentration of THC in surface water prevents the penetration of oxygen into the water, thus reducing its concentration. Also, fishes and other aquatic animals find it difficult to utilized the available oxygen within the environment because the oil covers the surface of the organs (gills) responsible for oxygen intake. Thus, increased THC impacts negatively on aquatic animals [31]. High levels of THC in water reduce the growth of aquatic plants and animals and thus affect the total output and value of the key production of phytoplankton, fish, shellfish and molluscs which literally possess objectionable odour or flavour, thereby reducing their marketability and acceptability for nutrition purposes as food.

\subsection{Nutrients in Water and Sediment Samples}

\subsubsection{Nitrates $\left(\mathrm{NO}_{3^{-}}\right)$}

The range of the concentrations of $\mathrm{NO}_{3}{ }^{-}$in this research fall within $4.2-5.7 \mathrm{mg} / \mathrm{L}$ for water and $0.495-5.21 \mathrm{mg} / \mathrm{Kg}$. the values in the water is lower than WHO requirement for drinking water. The concentrations of nitrates obtained in this work is lower than those observed in borehole water samples from Dass and Ganjuwa Local Government Area Bauchi, Nigeria [33], but higher than the values observed in the New Calabar River at point of effluent discharge [11] and those observed in a reservoir lake (Morna) in India [34]. The nitrates from this river may not have been affected or influenced by anthropogenic factors, but from decay of organic materials such as plants and animals and those that might have been carried or transmitted through runoffs from adjoining farmlands.

\subsubsection{Sulphates $\left(\mathrm{SO}_{4}{ }^{2-}\right)$}

The concentrations of Sulphates in water samples was found to range between $1956-2455 \mathrm{mg} / \mathrm{L}$, while the value in sediment ranged from $0.247-25.9 \mathrm{mg} / \mathrm{Kg}$. The values obtained in the water samples were higher than the standard required for any domestic water use by $\mathrm{WHO}$, whose limit is 250-500 $\mathrm{mg} / \mathrm{L}$. These values were higher than those of a previous researches in the water system $[35,36]$, in different aquatic environments in Nigeria and elsewhere in the world. Elevated levels of sulphate in water beyond the standard requirement is associated with some physiological disorders or ailments such as lack of water in the human system and gastro-intestinal irritation [37]. The presence of sulphates in water is always associated with some metal cations $(\mathrm{Pb}$ and $\mathrm{Fe})$ and anion $\left(\mathrm{PO}_{4}{ }^{3-}\right)$. Therefore, the presence of sulphates in water is an indication of the presence of salts of $\mathrm{Pb}$ and $\mathrm{Fe}$ in that media [38].

\subsubsection{Phosphates $\left(\mathrm{PO}_{4}{ }^{3-}\right)$}

The concentrations of phosphates in the water samples as observed in this study ranged from $0.45-0.83 \mathrm{mg} / \mathrm{L}$, which is lower than the requirement set by Who for drinking water. The concentrations observed in sediment samples varied from $0.247-0.268 \mathrm{mg} / \mathrm{Kg}$. The values of phosphates in this work is higher than those observed in water samples from Camligoze Dam Lake in Sivas Turkey [35], but slightly lower than the values of Edori and Nna, [11] in New Calabar River, Port Harcourt, Nigeria. The orthophosphates are the most predominant species of phosphate in most aquatic environments. Phosphate sources in the water samples may have originated from degeneration of organic matter, runoffs from agricultural lands where phosphate based fertilizers have been applied, animal dungs (piggery and poultry farms) and other sources. The consequence of phosphate increase in water or aquatic environment (water or sediment) is algal bloom (excessive growth of algae), which results in eutrophication especially in lakes and stationary water [23]. This will eventually lead to shallowness of the river, thus causing withdrawal of most bottom dwelling species that require certain level of depth to inhabit or dwell in any aquatic environment.

\subsection{Organic Carbon, Organic Matter and Textural Classification}

\subsubsection{Percentage Total Organic Carbon (\% TOC)}

The value of total organic carbon (TOC) recorded in this study fall within the range of $2.32-2.44 \%$. These values were of TOC observed in the present work from the different stations were below the values obtained in sediments of Adayar Estuary, Tamil Nadu, India [39], but within the range observed in sediments in Bengal, Bangladesh [40]. TOC 
mostly arises from anthropogenic sources. In any sediment, organic carbon tends to be at points where the flow of the river tends to be weak or low current and from effluents from carbon rich sources $[12,41]$. In this river, the organic carbon may have originated from illegal refining sources within and around the shores. The concentration of organic carbon (OC) correlates with the nature and size of the sediment particles. The not very high values of TOC in this work may be a consequence of the sediment particle size, which in this case is above $76 \%$ sand, which may not promote sorption of organic particles and inorganic minerals [12, 42].

\subsubsection{Percentage Total Organic Matter (\% TOM)}

The percentage value of total organic matter (TOM) in this work varied from $4.0-4.21$. These values from the Silver River are slightly higher or within the range of values obtained from the New Calabar River at different point of effluents discharge by Edori and Marcus [12], but lower than those observed in other works in the Persian Gulf [34], Ubatuba Bay in part of Brazil [43]. The sources of the organic matter in this river originated probably from natural sources, such as decay of plants and dead crustaceans (a common sea fish present within the area). Total organic matter is a parameter that give information on the nature and characteristics of the particles and its capacity to hold complex compounds. The higher the value of TOM, the implication that it can hold more minerals to itself, thus increasing heavy metal content of the sediment or soil.

\subsubsection{Percentage Clay, Silt and Sand and Textural Class}

The percentages of sand, clay and silt in the sediment samples in the examined stations varied from 76-80, 13-16 and $6-9 \%$ respectively. The textural class of the sediment was loamy sand. The percentage values of the different sediment showed that it contains more of sand than other particles. This implies that the grain sizes of the particles were large and thus may not have the capacity to hold contaminants within its spaces. The textural class is the degree of the physical characteristics or size of sediment or soil particles. Sandy nature of the sediment typifies a situation where the adsorption surface of the sediment is limited when compared to sediment surfaces that contains a larger percentage of clay and silt. Therefore, this sediment may allow easy movement of minerals, and organic constituents thus retaining little when compared to the original volume that may have been originally discharged into the river.

\section{Conclusion}

The study revealed that the river has been greatly interfered with by human factors. This assertion was based on the fact that most of the physicochemical parameters examined in the water are already giving warning signals of high level of contamination or pollution by chemical components. However, sediment physicochemical qualities did not show possible signs of warning except for the high conductivity values observed. This may probably be not as a result of input of pollutants, but the nature of the sediment (texture) which allows for proper transport of materials on bed sediments. Therefore, governmental efforts should be put in place to determine input sources of pollutants and put preventive measures in place so that there will be improvement or reduction in the pollution or contamination of the river. This will enable the locals to make proper use of the water as was done in decades past.

\section{References}

[1] Shrestha, S., Kazama, F. (207). Assessment of surface water quality using multivariate statistical techniques: A case study of the Fuji river basin, Japan. Environmental Modelling and Software, 22: 464-475.

[2] Dan'azumi, S. and M. H. Bichi, 2010. Industrial Pollution and Heavy Metals Profile of Challawa River in Kano, Nigeria. Journal of Applied Sciences in Environmental Sanitation, 5 (6): 56-62.

[3] Kpee, F. and Ekpete, O A. (2014). Levels of trace metals in surface sediments of Kalabari Creeks, Rivers Stae, Nigeria. Journal of Applied Science and Environmental Management, 81 (2): 189-195.

[4] Gerba, C. P. and Smith, J. E., (2005). Sources of pathogenic microorganisms and their fate during land application of wastes. Journal of Environmental Quality, 34: 42-48.

[5] Iyama, W. A. and Edori, O. S. (2016). Comparative analysis of the water quality status of the Bassan rivers in Bayelsa State, Nigeria. International Journal of Chemistry and Chemical Engineering, 6 (1): 59-69.

[6] Walkey, A. and Black, A. I. (1934). An examination of the Dagtjareff method for determination of soil organic matter and a proposed modification of the chromic acid titration method. Soil Science, 37: 2938.

[7] Marcus, A. C. and Edori, O. S. (2017). Physicochemical characteristics at point of a receiving waterbody at Ekerekana, Rivers State, Nigeria. Journal of Chemical Society of Nigeria, 42 (1): 62-67.

[8] Turekian, K. K. and Wedepohl, K. H. (1961). Distribution of elements in some major units of the earth's Crust. Bulletin of Geology Society of America, 72: 175-192.

[9] Ekpete, O. A. (2002). Physicochemical determination of river water in Odhiolugboji community in Rivers State. Journal of Vocational Science and Educational Development, 3 (1): 2529.

[10] Iyama, W. A., Edori, O. S. and Ede, P. N. (2019). Physicochemical Assessment of Surface Water Quality around the Sagbama Creek Water Body, Bayelsa State, Nigeria. Global Journal of Science Frontier Research B: Chemistry, 18 (2): 1-10.

[11] Edori, O. S and Nna, P. J. (2018). Determination of physicochemical parameters of effluents at discharge points into the New Calabar River along Rumuolumeni axis, Niger Delta, Nigeria. Journal of Environmental and Analytical Toxicology, 8 (3): DOI: 10.4172/21610525.1000585 . 
[12] Edori O. S. and Marcus A. C. (2019). Some Sediment Physicochemical Parameters at Effluents Discharge Points of New Calabar River along Rumuolumeni Axis, Port Harcourt, Niger Delta Nigeria. Chemistry Research Journal, 4 (1): 67-73.

[13] Murhekar G. H. (2011). Determination of physicochemical parameters of surface water samples in and around Akot City. International Journal of Research in Chemistry and Environment, 1 (2): 183-187.

[14] Borkar, A. D. (2015). Studies on Some Physicochemical Parameters of Soil Samples in Katol Namita Taluka District Nagpur (MS), India. Research Journal of Agriculture and Forestry Sciences, 3 (1): 16-18.

[15] APHA (1985). Standard methods for the examination of water and wastewater treatment, 12th Ed. American Public Health Association, New York.

[16] Nazir, R., Khan, M., Masab, M. and Rehman, H. U. (2015). Accumulation of Heavy Metals ( $\mathrm{Ni}, \mathrm{Cu}, \mathrm{Cd}, \mathrm{Cr}, \mathrm{Pb}, \mathrm{Zn}, \mathrm{Fe}$ ) in the soil, water and plants and analysis of physicochemical parameters of soil and water Collected from Tanda Dam Kohat. Journal of Pharmaceutical sciences and Research, 7 (3): 89-97.

[17] Joshi, D. M., Alok Kumar, A. and Namita Agrawal, (2009). Studies on Physicochemical parameters to assess water quality of River Ganga for drinking purpose in Haridwar District, Rasayan Journal, 3 (1): 16-18.

[18] Ikeme, C. H., Dioha, I. J., Olasusi, K. A., and Chukwu, U. P. (2014). Physicochemical analysis of selected borehole water in Umuihi Town, Imo State, Nigeria. International Journal of Scientific and Engineering Research, 5 (8): 680-689.

[19] Rahmanian, N., Ali, S. H. B., Homayoonfard, M., Ali, N. J., Rehan, M., Sadef, Y. and Nizami, A. S. (2015). Analysis of Physiochemical Parameters to Evaluate the Drinking Water Quality in the State of Perak, Malaysia. Journal of Chemistry, 2015, Article ID 716125, 10 pages http://dx.doi.org/10.1155/2015/716125.

[20] Davies, O. A., Teere, M. B. and Nwose, F. A. (2018). PhysicoChemical Variables of the Upper Reaches of Orashi River, Niger Delta, Nigeria. Journal of Agricultural Sciences and Research, 1 (1): 51-63.

[21] Dienye, H. E. and Woke, G. N. (2014). Physico-chemical Parameters of the Upper and Lower Reach of the New Calabar River Niger Delta. Journal of Fisheries and Livestock Production, 3 (4): DOI: 10.4172/2332-2608.1000154.

[22] NRCC (National Research Council of Canada) (2011). Effect of sodium and potassium in the Canadian environment. NO. 150154. Associate Committee on Scientific Criteria for Environmental Quality Otttawa.

[23] Edori, O. S. and Kpee, F. (2016). Physicochemical and heavy metal assessment of water samples from boreholes near some abattoirs in Port Harcourt, Rivers State, Nigeria. American Chemical Science Journal, 14: 1-8.

[24] Yapo, T. W., Mambo, V., Yapo, O. B., Seka, M. A. and Houenou, P. V. (2012). Physicochemical evaluation of wastewater from the main sewer in Abidjan city. Journal of Ecology and the Natural Environment, 4: 1-5.

[25] Gupta, N., Pandey, P. and Hussain, J. (2017) Effect of physicochemical and biological parameters on the quality of river water of Narmada, Madhya Pradesh, India. Water Science, 31: 11-23.
[26] Premlata, V. (2009). Multivariant analysis of drinking water quality parameters of Lake Pichhola in Udaipur, India. Biological Forum-An International Journal 1: 97-102.

[27] Kataria, H. C., Quershi, H. A., Iqbal, S. A. and Shandilya, A. K. (1996). Assessment of water quality of Kolar reservoir in Bhopal (MP). Pollution Research, 15: 191-193.

[28] Iyama, W. A. and Edori, O. S. (2014). Seasonal variation in water quality during dredging of brackish water habitat in the Niger Delta, Nigeria. Trends in Applied Sciences Research, 9 (3): 153-159.

[29] Sawyer, C. N. (1994). Chemistry, pp: 103-104. McGraw Hill Book Co., USA.

[30] Sharma, N. and Walia, Y. K. (2017). Water quality investigation by physicochemical parameters of Satluj River (Himachal Pradesh, India). Current World Environment, 12: 174-180.

[31] Howard, I. C., Gabriel, U. U. and Horsfall, M. (2009). Evaluation of total hydrocarbon levels in some aquatic media in an oil polluted mangrove wetland in the Niger Delta. Applied Ecology and Environmental Research, 7 (2): 111-120.

[32] Wokoma, O. A. F. (2014). Levels of total hydrocarbon in water and sediment of a polluted tidal creek, Bonny River, Niger Delta, Nigeria. International Journal of Scientific and Technology Research, 3 (12): 351-354.

[33] Chindo, I. Y., Karu, E., Ziyok, I. and Amanki, E. D. (2013). Physicochemical analysis of ground water of selected areas of Dass and Ganjuwa local government areas, Bauchi State, Nigeria. World Journal of Analytical Chemistry, 1: 73-79.

[34] Agah, H., Rahmanpour, S., Sheijooni Fumani, N. (2013). Organic carbon and organic matter levels in sediments of the Strait of Hormoz, the Persian Gulf. Journal of the Persian Gulf (Marine Science), 4 (13): 31-37.

[35] Dirican, S. (2015). Assessment of water quality using physicochemical parameters of Çamlıgöze Dam Lake in Sivas, Turkey. Ecologia, 5 (1): 1-7.

[36] Okoro, N., Omeje, E. O. and Osadebe, P. O. (2017). Comparative Analysis of Three Borehole Water Sources in Nsukka Urban Area, Enugu State, Nigeria. Resources and Environment, 7 (4): 110-114.

[37] Jidauna, G. G., Dabi D. D., Saidu, B. J., Ndabula, C. and Abaje, I. B. (2014). Chemical water quality assessment in selected location in Jos, Plateau State, Nigeria. Research Journal of Environmental and Earth Sciences, 6 (5): 284-291.

[38] WHO (2011). Guidelines for Drinking Water Quality. $4^{\text {th }}$ Edition, WHO Press, Switzerland.

[39] Nandini, S. and Milton, M. C. J. (2018). Assessment of the Physico-Chemical Parameters of Sediment of Adayar Estuary, Tamil Nadu, India. International Journal of Research in Advent Technology, 6 (9): 2474-2481.

[40] Rashedul, A., Chowdhury, S. M. and Mohammad, Z. (2018). Physicochemical parameters of water and sediment during spring period in parts off Bay of Bengal, Bangladesh. MOJ Ecology and Environmental Sciences, 3 (3): 150-154.

[41] Kamaruzzaman, B. Y., Siti Waznah, A., Ong, M. C. Shahbudin, S. and Jalal, K. C. A. (2009). Variability of organic carbon content in bottom sediment of Pahang River estuary, Pahang, Malaysia. Journal of Applied Sciences, 9 (24): 4253 4257. 
[42] Kennedy, H. E., Gacia, D. P., Kennedy, S. P. and Duarte, C. M, (2004). Organic carbon sources to SE Asian Coastal sediments. Estuarian Coastal Shelf Science, 60: 59-68.
[43] Burone, L., Muniz, P., Pires-Vanin, A. M. S. and Rodrigues, M. (2003). Spatial distribution of organic matter in the surface sediments of Ubatuba Bay (Southeastern- Brazil). Annals of the Brazilian Academy of Sciences, 75 (1): 77-90. 